\title{
Borgos, Anna. 2018. Holnaplányok: Nök a pszichoanalízis budapesti iskolájában ('Girls of Tomorrow: Women in the Budapest School of Psychoanalysis'). Budapest: Noran Libro Kiadó. 300 pp. Illus.
}

\author{
Reviewed by Anita Kurimay, Bryn Mawr College
}

Holnaplányok: Nök a pszichoanalizis budapesti iskolájában ['Girls of Tomorrow: Women in the Budapest School of Psychoanalysis'] explores the lives of the first two generations of Hungarian female psychoanalysts from the early twentieth century to the post World War II era. Based on extensive research and a wide array of sources, the book provides not only captivating life stories of some of the most prominent female Hungarian psychoanalysts but also an illuminating portrayal of the tumultuous relationship of the experiences of these New Woman, Jewishness, and psychoanalysis during the first half of the twentieth century.

The book opens with a brief overview of classical psychoanalytical theories on womanhood. In her discussion of the psychoanalytical ideas of Sigmund Freud and his followers on femininity and female sexuality, Anna Borgos sets the stage for the inherent contradiction between psychoanalytical theories as embedded in and propagating a patriarchal and malecentered world and psychoanalysis as a profession that enables the success and high representation of women among its practitioners. While Freud, along with many of his male colleagues, theorized women as passive and considered intellectual aspirations in women as a masculine wish serving to compensate for failed femininity, Borgos highlights how, in practice, women took on important roles within the psychoanalytical profession from early on. Borgos's overview of Freudian psychoanalytical theories and terminology on women's "passivity, masochisms, narcissism and penis envy" (25) and her introduction of some of the most wellknown female analysists in Freud's immediate circle (including Anna Freud, Helene Deutsch, Karen Horney, Joan Riviere, Melanie Klein, Sabina Spielrein, and Lou Andreas-Salomé) exemplifies her ability to distill complex psychoanalytical theories for even a general audience. This capacity, which reverberates throughout the entire book, along with a nuanced approach to discussing psychoanalytical ideas, shows that already in the profession's earliest days there were varied alternative theoretical views on women. Ultimately, Borgos illustrates how, in theorizing about women, Freud and his followers were deeply rooted in the bourgeois gender norms of their times. At the same time, this book pays attention not only to what Freud said but also to what he did as a proponent of women's equality, sexual education, and female psychoanalysts. In all these regards Freud is proven to have lived and acted ahead of his time.

*akurimay@brynmawr.edu

(cc) BY

ULIS D-ferle
New articles in this journal are licensed under a Creative Commons Attribution 4.0 International License.

This journal is published by the University Library System of the University of Pittsburgh as part of its D-Scribe Digital Publishing Program and is cosponsored by the University of Pittsburgh Press 
Kurimay, Anita. "Borgos, Anna. 2018. Holnaplányok: Nők a pszichoanalizis budapesti iskolájában ('Girls of Tomorrow: Women in the Budapest School of Psychoanalysis'). Budapest: Noran Libro Kiadó. 300 pp. Illus." Hungarian Cultural Studies. e-Journal of the American Hungarian Educators Association, Volume 13 (2020) DOI: 10.5195/ahea.2020.401

The second chapter contextualizes the social and political background of female analysists as well as, more generally, the rise of psychoanalysis in fin-de-siècle Budapest and Central Europe. Borgos makes a compelling case for why, during the initial year of its professionalization, psychoanalysis provided middle-class, assimilated or secular Jewish women a place to thrive. The liberal politics of pre-World War I Hungary contributed to a growing secular Jewish population that fostered higher education for girls and supported female employment. This was a time when opportunities for women were expanding and they could increasingly enter formerly male professions such as law and medicine. Psychoanalysis (like photography among the arts) as a new profession lacked the traditional hierarchies of the longestablished medical professions, which made it much more welcoming for women. In addition, the concerns of psychoanalysis with the healing of the self and with emotionality, which had been traditionally associated with women, also served to raise its appeal among young educated women. Finally, notwithstanding Freud's openminded-ness toward women in this new profession, Borgos also clarifies that, compared to Freud's Vienna School, Sándor Ferenczi's Budapest School was even more supportive of female psychoanalysts.

The subsequent five chapters in Borgos's book detail the lives of five of the most prominent pioneer Hungarian female psychoanalysts: Lilly Hajdu, Edit Gyömrői, Alice Bálint, Vilma Kovács, and Lillián Rotter, whose careers unfolded in Budapest, Vienna, Prague, Berlin, Ceylon, London, Paris and Los Angeles. Each chapter discusses its protagonist's familial and social background, how she became involved in psychoanalysis, and her professional foci and contribution to the field. In addition, in each of the chapters Borgos foregrounds a particular set of primary sources, diaries, letters, and in one case an autobiographical novel, that altogether offer a glimpse into to the lives of these incredible women and, in particular, their reflections on contemporary womanhood, psychoanalysis, and the rapidly changing worlds around them. Whether these sources concern the women's professional trajectory, such as Lilly Hajdu's attitude to Pavlovian theory, or family issues, as in the case of Edit Gyömröi's relations with her son Gábor, these longer excerpts of primary sources accompanied by Borgos's historical contextualization, which she does with empathy combined with critical commentary, are definitely the highlights of the book.

Lilly Hajdu, who stand behind the book's title of "holnaplányok" ['tomorrow's girls'], owing to the expression she used regarding herself while in medical school, and like her all the rest of the women in the book indeed represented the New Woman. These women had abandoned traditional ideals of femininity and considered themselves as intellectuals and as equal partners to men. For example, Lilly Hajdu wrote to her boyfriend and future husband: "[I] am the future and a woman of the future. And I would like to believe that women [of the future] will be like myself in their maturity and will not conform to men" ['...jövö, holnapnö vagyok. $S$ én szeretném hinni, hogy a nök hozzám hasonlóak lesznek majd fejlödésük magasabb stádiumaiban, s nem a férfiakhoz idomulnak'] (80 -81). As Borgos's careful reconstruction of the lives of Hajdu and the other women in her book illustrates, while all of these women operated within the confines of patriarchy, it often turned out to be not necessarily their greatest obstacle for their professional success.

Borgos uses her protagonists' lives to explore the effects of major political changes and forces (such as the brief communist rule of 1919, the growing antisemitism of the interwar era culminating in the Holocaust, and the establishment of communist dictatorship following 1949) on the lives of Jewish women and on psychoanalysis. One of the book's many merits is the 
Kurimay, Anita. "Borgos, Anna. 2018. Holnaplányok: Nők a pszichoanalizis budapesti iskolájában ('Girls of Tomorrow: Women in the Budapest School of Psychoanalysis'). Budapest: Noran Libro Kiadó. 300 pp. Illus." Hungarian Cultural Studies. e-Journal of the American Hungarian Educators Association, Volume 13 (2020) DOI: 10.5195/ahea.2020.401

author's ability to thread the life stories of these individual women into the political situation with its social and professional components, all without overbearing her ultimate aim, which is to highlight the contribution of these women to psychoanalytical theory, practice, and training. The result of this structuring is the realization that despite the tremendous obstacles and hardships that these professionals faced as women, Jews, and innovative therapists and theoreticians, they ought to be commanded and remembered as active agents who made an important contribution to psychoanalysis in trying times. Whether it was on their approaches to schizophrenia (Hajdu), or analysis of a concentration-camp victim (Gyömröi), or calling attention to children's issues and to mother and child relationships (Bálint), the establishment of the Budapest School (Kovács), or challenging Freud's theories on female passivity (Rotter), Holnaplányok honors the professional legacy of these novel psychoanalysts.

The last part of the book provides a brief overview of the lives and psychoanalytical contributions of twenty-seven lesser-known female analysts who were contemporaries of the five analysts at the center of Borgos's study. Of these, those who left Hungary ended up working abroad as analysists, while those who stayed and survived the Holocaust had to work, due to the communist ban on practicing psychoanalysis, as teachers, translators, and librarians. As Borgos's concluding remarks make clear, the first generation of Hungarian female analysts brought a new (female or woman's) perspective to psychoanalysis yet had also a much more difficult time compared to their male counterparts distancing themselves from Freud's initial theories on gender. Only at Sándor Ferenczi's Budapest School were female analysts able to make theoretical contributions and become leaders in training and practicing, while most other whitecollar professions relegated women to the sidelines.

Having portrayed the lives of these women analysts through highlighting their talents and agency, Borgos concludes her book with the realization that the paths of these women and of the psychoanalytical profession were heavily influenced by the historical events and socio-political forces of their time. To no less extent, issues of Jewishness, womanhood, and male-dominated psychoanalysis have also clearly shaped the lives of Borgos's protagonists. While at the turn of the twentieth century it was their womanhood that constituted an obstacle for their professional development, in the interwar period and especially from the 1930s and on it was their Jewishness. And if they stayed in Hungary during the Cold War it became their psychoanalytical profession that hindered them. It would have added to the rather short conclusion to reflect on the specific reasons why some of the five women became more successful in the psychoanalytical profession and also why certain professional legacies have later become more acknowledged than others. This is a relatively minor criticism, however, of a book that otherwise shows remarkable range in its coverage. Anna Borgos's Holnaplányok is highly engaging and should be of great interest for people interested in the history of psychoanalysis and in women's and Hungarian-Jewish history. 